\title{
Blame-game politics: Re-evaluating incongruent leprosy and COVID-19 policies in the Old Testament and Nigerian societies
}

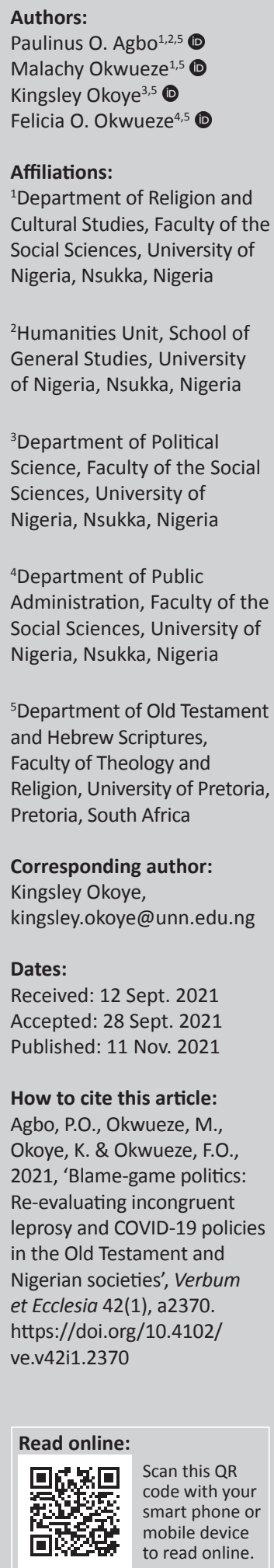

History is rife with political actors framing policies to absolve themselves from blame. Such policies seem integral to governance. Studies have shown how the outbreak of diseases triggers policy changes from different governments, especially during the present day coronavirus disease 2019 (COVID-19) pandemic. The 'Old Testament (OT) leprosy', particularly as found in Leviticus 13 and 14, prompted incongruent policies that occasioned the victimisation and destruction of suspected lepers' houses. Similarly, some who breached the COVID-19 lockdown protocols in Nigeria were tortured, victimised or killed. Investigations on these overbearing regulations are linked to ignorance and autocracy on the part of policy formulators and implementers. There has likely not yet been any study examining this phenomenon from the purview of blame-game politics resulting from poor leadership decisions. This work, therefore, reviewed the government's policy response to leprosy in the OT and the Nigerian government's response to COVID-19 lockdown regulations with the view to assess their suitability in their specific contexts. The texts of Leviticus 13 and 14 were examined through the analytical principles of hermeneutics. Documentary method of research was also used to interpret other secondary data to draw relations between the two governments' shifting of responsibilities and victimisation of citizens, both in the OT and Nigerian societies.

Intradisciplinary and or interdisciplinary implications: This research drew on the theories in philosophy, ethics, political science, psychology and sociology. The findings indicated that policy formulators and or implementers employed blame-game constructs as response to leprosy and COVID-19 both in OT and contemporary Nigerian society, respectively.

Keywords: blame-game; politics; Old Testament; leprosy; COVID-19 policy; Nigeria.

\section{Introduction}

Mastering the art of avoiding blame and the shirking of their responsibility in order to preserve their self-image are common amongst different individuals and human groups. The initial reaction of an average individual when something goes wrong is to try to attribute the wrongdoing to someone else or a group. Norz (2015:1) contended that 'we all play this blame-game because it provides some measure of satisfaction to have a simple, straightforward explanation of undesirable events that happen in our lives'. A number of scholars agree that the tactic of blame-game is an important variable in people's interaction in society (Hansson 2017:472-475; Shurafa, Darwish \& Zaghouani 2020:333-359). In governance, for instance, it is employed to achieve a desired political goal (Hood 2002:36). The outbreak of șarra'at ${ }^{1}$ (leprosy), as shown in parts of the Old Testament (OT), particularly Leviticus 13 and 14, prompted policy constructs suggestive of blame-game. Both suspected and 'diagnosed lepers' experienced various degrees of victimisation, including the destruction of their houses (Lv 14:45). In other instances, leprosy is perceived as Yahweh's punitive measure for sinners or transgressors (Nm 12:10; Ex 4:6-7; 2 Ki 20; $2 \mathrm{Sm} \mathrm{3:9} \mathrm{etc.).} \mathrm{This} \mathrm{line}$ of thinking could have triggered exclusionary social behaviour against the 'outsider' (lepers or suspected lepers) within the same social circle. In a similar vein, the framing of policies during the coronavirus disease 2019 (COVID-19) lockdown protocols in Nigeria resulted in the harsh \footnotetext{
1.Şära at, also transliterated as tsara'at or Sara'ath, is a Hebrew term for a disease that affects the body, cloth/garment, leather, walls of
houses, etc. as shown in the Old Testament. The disease is translated in the Bible as an equivalent of Hansen disease (modern leprosy), houses, etc. as shown in the Old Testament. The disease is translated in the Bible as an equivalent of
a position that is challenged by many scholars (see, e.g., Deps \& Cruz 2020:1; Olanisebe, 2014:121).
}

Copyright: (C) 2021. The Authors. Licensee: AOSIS. This work is licensed under the Creative Commons Attribution License. Note: Special Collection: African Hermeneutics. 
treatment of some vulnerable citizens. Some of the victims who breached the regulations were tortured, killed or their houses were destroyed by security forces (Ezeibe et al. 2020:1757; Odigbo, Eze \& Odigbo 2021:6; Orjinmo 2020:1). Similar brutality (torture/killing) from the security forces on innocent citizens during the COVID-19 lockdown protocols was on the rise in South Africa, Uganda, Kenya and other places also (Katana et al. 2021:2). Interestingly, a further probe of the mitigating policies against the outbreak of leprosy and COVID-19 in the two societies under study shows a consistent resemblance with scapegoating. Despite the emotional burden and painful experiences that the victims of blame-game undergo (Perera 1986:221-230), governance theorists extol blame avoidance as a means of improving the quality of governance, management and organisational design (Hinterleitner 2018:221; Hinterleitner \& Sager 2016:587; Hood 2010:1-10; Hood, Jennings \& Copeland 2016:559). However, another school of thought views the politics of blame-game as amoral and unethical (Langford 2011:595). Indeed, the significant moral question associated with scapegoating has not diminished its role in governance. Studies on OT leprosy described the unwholesome treatment of lepers, namely stigmatisation and scapegoating (Lewis 1987:593; Olanisebe 2014:121). Other findings portrayed governance (Yahweh's) legislation and policy framing (Wenham 1979:15-23) as sources of the incongruent treatment of lepers. No known study has examined the administrative policy response to sara'ath as a conscious politics of blamegame on the part of the ancient Jewish policymakers and leaders. In the same vein, the outbreak of COVID-19 has triggered a policy response that aided the victimisation of citizens who breached the lockdown protocols in Nigeria (Odigbo et al. 2021:1; Oboirien 2020:1-2). None of the studies on this overbearing policy seems to have implicated the politics of blame-game by the political actors and policy formulators and implementers. In light of this lacuna, this article provides evidence that the core policy responses to the outbreak of both the leprosy in Leviticus 13-14 and COVID-19 in Nigeria coincide with the politics of blame-game.

The ancient Hebrew society of the Leviticus period was saddled with numerous challenges, including the outbreak of an 'incurable' șära'at. The numerous offerings to Yahweh (Lv 9:7-21) provide a clue as to the aspirations and wishes of the Jews against war, famine and afflictions. Notable political figures, such as Moses ( $\operatorname{Lv} 1-7,11-27)$, Aaron ( $\operatorname{Lv} 8,1-7$, 11-27) and other anonymous priests could not provide enduring answers and solutions to these misfortunes except the increased rituals and sacrifices to Yahweh ( $\operatorname{Lv} 1-7,1: 1-17$, 2:1-16, 3:1-17, 4, 7; 11-35). Our knowledge about the reasons for scapegoating (see Kirwan 2005:1-10) shows the inevitability of finding a black-sheep/object of blame in a situation of unresolved crises capable of implicating the political or social class for poor performance. This view is consistent with Girard's scapegoat mechanism (see Palaver 2010:128). It is on this note that the disproportional policies of victimisation of lepers could be contextualised. In the same vein, the policy of torture and victimisation of the citizens during the COVID-19 lockdown protocols by Nigerian government evinces the politics of blame-game. Nigerian leaders' notoriety in poor policymaking and implementation in every sector of governance (Ayodeji \& Adebayo 2015:12; Odukoya, Bowale \& Okunlola 2018:4) is well known. Most of the citizens are treated with utmost negligence. There are criticisms of bad governance, including inhumane/draconic responses to issues of the COVID-19 outbreak (Abubakar 2021:23; Adegbami \& Adepoju 2017:148; Amadasun 2020:1). Leaders are increasingly blamed for the poor control of the influx of COVID-19 positive individuals into Nigeria, as well as the poor healthcare provision (Ezeibe et al. 2020:1754). Nevertheless, the harsh treatment of those who flouted the COVID-19 lockdown protocols appears to be an attempt to pass the blame on the citizens as the cause of the spread of the virus.

This article specifically investigated the governance policy responses to leprosy in the ancient Jewish period (as particularly found in the Book of Leviticus), and the government's policy response to COVID-19 in the contemporary Nigerian society, respectively. We drew from the scapegoat theory, which stresses blaming a person or group for one's own misdeeds or failures, to show that the government policy responses to the outbreak of leprosy and COVID-19 in the two societies under study are instantiations of a conscious blame avoidance strategy. We also demonstrate that the act was an opportunity to maintain the leaders' selfimage in order to deflect attention away from their misdeeds and failures.

\section{Methods}

The data for this study were mainly obtained from secondary sources. Through the analytical principles of hermeneutics, the texts of the OT, particularly Leviticus 13 and 14, that depict the diagnosis, causes and remedies of Sara'ath (leprosy) were interpreted. The aspect of hermeneutics that deals with the literary/critical interpretation of Biblical texts was employed. The 'plain meaning', context and grammatical constructions in the aforesaid pericope were critically examined. A purposive method was used to select Leviticus 13 and 14 because these two chapters deal primarily with incongruent policy response to leprosy in the OT. These chapters were analysed to establish blame-game politics as a response to leprosy. In line with the OT textual provisions, we reviewed scholarly journal articles, books, newspaper articles and periodicals on the politics of blame-game, police brutality and corruption during the COVID-19 lockdown. Documents from the national government, non-governmental organisations, genocidal reports, etc. were reviewed, and important variables therein were used in the literature and discussion. The data were analysed using inferences, logical arguments and content analysis. The article was structured into four sections. Part one provides the introduction and background to the study. Part two explains the politics of blame-game in Leviticus 13 and 14. The politics of blamegame during the outbreak of COVID-19 in Nigeria is described in part three. Part four shows the implications of the politics of blame-game as a response to leprosy in OT and 
COVID-19 in Nigeria. In the last part, the article concludes that the incongruent and harsh treatment of lepers/suspected lepers and those who breached COVID-19 lockdown protocols, respectively, in the OT and Nigerian societies were efforts to protect the self-image of the leaders as well as policy formulators and implementers.

\section{Theoretical underpinning}

Scapegoat theory explains the tendency to blame someone else for one's own problems or wrongdoing (Mellema 2010:3-9), often resulting in feelings of prejudice towards the person or group being blamed (Hammer 2007). Different scholars have corroborated Hammer and Mellema's views and understanding of the theory (see Gibson 2007:194; Glick 2005:244). Crossman (2019:1) added that in the process of scapegoating, the real source of the problem linked to the scapegoated individual or groups is either never seen or purposefully ignored. At the centre of the blame-game is the idea to explain failure or misdeed whilst maintaining one's positive image (Hammer 2007). The reasons for scapegoating vary, but fear is often the most prevalent: fear of the stranger, fear of punishment and fear of change (Mallan 2013:65-89). Discourses on scapegoat theory explain the blame-game from mainly political, sociological, economic and psychological perspectives (Dellis 2007:79; Hood 2010; Lee \& Robinson 2000:1853; Niyimbanira \& Madzivhandila 2016:165-175). In politics, for instance, certain governance policies are shaped by blame-game/scapegoating. Many scholars are in agreement that scapegoating was the impetus of the prejudice and genocide against the Jews by the Nazis (Brustein \& King 2004:37; Glick 2002:126, 2005:244-261). The Jews were wrongly blamed for the hardship and economic woes in Germany after the First World War. The Holocaust is a classic example of the challenging application of scapegoating in governance. Similar to this, is the genocide of the minority Tutsi in Rwanda who were erroneously blamed for the socio-economic and political challenges of the majority Hutus (Vandenhole 1996:345). Scapegoating can be experienced on: (1) one-on-one level: when a person blames another for something s/he did; (2) one-on-group level: when a person blames a group for his/her own mistakes/misdeeds; (3) group-on-one level: when a group scapegoats one person as the cause of their misfortunes or failures and (4) group-ongroup level: when group $X$ blames group $Y$ for a problem not caused by group $\mathrm{Y}$.

Following the use of the concept of the scapegoat in modern parlance to describe the art of blame-game, we (tend to) forget that originally scapegoat was a human or animal victim chosen for sacrifice to the underworld god to propitiate god's anger to heal the community as shown in Leviticus 16 (Perera 1986:221-230). In ancient Greece, human scapegoats (pharmakos) were used to mitigate a plague or other calamity or even prevent such ills (Compton 2006:1-10). The phenomenon, which has been described as old as the human society, evolved in all spheres of human endeavours, as indicated earlier. As reported by Dawson (2013:1), the coinage of the concept 'scapegoat' was generally credited to William
Tyndale for his 1530 translation of the Bible, where he used it to describe one of the two goats chosen by lot to be sent alive into the wilderness, the sin of the people having been symbolically laid upon it. The sense in which the term is used in contemporary scholarship does not seem to presuppose that transference of guilt (as was the case in ancient societies) to the person, animal or object being scapegoated (Mellema 2010:3-9).

From the foregoing, the scapegoat theory fittingly explains the pattern of government policy responses to leprosy in the OT and the outbreak of COVID-19 in Nigeria. In Leviticus 13 and 14 and other parallel passages, for instance, the theme of the causes and management of leprosy are conspicuously present. A cursory and uncritical reading of the aforementioned chapters could lead to a contextualised/ subjective understanding of Yahweh as the source of the harsh treatment of lepers/suspected lepers. It is deductible from the prevailing motif in the OT that every aspect of human activity is linked to Yahweh (Houston 2007:1), even when it is ridiculous to make such a connection. The activities of priests and other leaders (Schultz 2002:24), at some levels, are left to their individual choices and intuitions. In a similar vein, Lewis (1987:599), citing Robert Smith, noted that political circumstances affect beliefs and ethical considerations and framing in the Bible. Drawing from this, the policy to ostracise, banish or destroy the houses of the lepers was likely a conscious scapegoating of the out-group who were distinguished by their dermatological conditions. Even those who were suspected to be infected with Sara'at passed through various degrees of victimisation (Grzybowski \& Nita 2016:3). The Jews during the period of Leviticus and, by extension, during the Pentateuchal era, were intermittently critical of their leaders, including Moses, Aaron and the children of Aaron (Heike 2018:68-70; Margaliot 1983:198), and an attempt to shift the leadership responsibility and failures to the vulnerable citizens was inevitable to protect their self-image. Scapegoat theory aptly captures this aspect of governance behaviour. Our knowledge of Mimetic theory (Gallese 2009:21-30; Palaver 2010:127) reveals that the rituals connected to the entire process of identification, ostracism and other harsh treatments of lepers, which is alluded to the symbolic scapegoat in Leviticus 16, are common practices amongst ancient societies. The in-group represented by the Jewish leaders feared the impending retribution from Yahweh for their perceived sin and presumed leprosy as the effect of sin, resulting in the scapegoating of lepers or suspected lepers.

Similarly, the ruthless treatment of people suspected of having COVID-19 or measures to forestall the spread of the disease in Nigeria coincides with the politics of blame-game. Nigeria leaders are notorious for endemic corruption (Deckard \& Pieri 2017:372; Ebekozien 2020:2; Olujobi \& Olujobi 2020:338; Omonijo, Nnedum \& Uche 2013:2; Demarest 2020:2), lack of empathy for the citizens (Ehigie, Kolade \& Afolabi 2006:413) and so on. From social media to academic writings, increasing criticisms of the leaders abound. There are efforts for a change of government because 
of visionless policies and the indifferent attitude of the leaders to the plight of Nigerians. Many Nigerians have died from preventable diseases, with the government paying lip service to their claim of improving the health facilities (Akokuwebe \& Adekanbi 2017:2). The outbreak of COVID-19 exposed Nigeria's dire and poor health facilities (Onigbinde, Babatunde \& Ajagbe 2020) and challenging experience of controlling the influx of people who contracted the dreaded disease into the country. To remain blameless and for the protection of their cherished image, the leaders' response to COVID-19 seemed as though the citizens were responsible for allowing the COVID-19 index case and others who contracted the disease into Nigeria. The leaders who are believed to be apathetic to the sufferings of ordinary citizens suddenly started acting as if they are genuinely concerned about them. Although the reason that was made public by the officials of the government seemed to support keeping Nigeria safe from COVID-19, the ensuing high-handed approach by the law enforcement agents during the lockdown provoked mixed feelings and reactions from critics (Aborisade 2021:2-3). Breaching the COVID-19 protocols of lockdown attracted torture, death and the destruction of houses (Ezeibe et al. 2020). However, the questionable behaviour of Nigerian leaders towards the citizens could be exemplified in the revelation that the COVID-19 palliatives expected to be given to those who observed the lockdown protocols were most likely hoarded by government officials and leaders (Dabang \& Ukomadu 2020:1-2). None of these shortcomings to mitigate the spread of the virus seemed to have bothered the leaders. Rather, some vulnerable citizens, amid their grave financial difficulty, were maimed or killed as they searched for their daily bread (source of livelihood) through controversial lockdown regulations. Indeed, what best describes this trend of shifting blame from the leaders to the citizens (represented by those who flouted the lockdown regulation) is the instantiation of scapegoat theory.

\section{Locating the politics of blame-game in Leviticus 13 and 14}

The concept of politics has attracted incongruent and divergent meanings from scholars of politics (Modebadze 2010:39-43; Nnoli 2003:1-19). Drawing from the extant literature on politics (e.g. Barnett \& Duvall 2005:39-69; Wittes 2016:6-8), the art of governance and organisation of society are common variables connected to the idea of politics. Through the instruments of power and/or authority, many leaders have managed state resources and controlled the citizens to achieve societal goals. Others, through their personal shortcomings, behavioural challenges and issues related to religion, race, stereotype and so on, become tyrannical and divert state resources to personal use, whilst victimising other citizens (Lumumba 2014:17-30). As previously observed, studies have shown how the art of scapegoating is used in governance by various political leaders. Leaders who have failed in their responsibilities often engage in buck-passing by blaming the vulnerable members of society in order to protect their own image. Considering Rene Girard's four scapegoat stereotypes,
Skidmore (2020:893) validated the aforesaid claim as he maintained that the rituals presented in Leviticus 13:1-46 have evolved from an earlier tradition in which sara'at patients were executed to halt the mimetic crisis. In other words, the expelling or killing of the scapegoated individual or group was a means of solving the intractable conflicts in ancient societies. With this background, this section is set to locate the use of blame-game politics in the OT Leviticus 13 and 14 as the ancient Hebrew society battled the outbreak of sara'at.

The Book of Leviticus, which contains the text ( $\operatorname{Lv} 13$ \& 14) under study, is part of the Pentateuch (the first five books of the OT, namely Genesis, Exodus, Leviticus, Numbers, and Deuteronomy), traditionally believed to have been written by Moses. The Pentateuch, otherwise known as the Torah or the book of the law, was presumed by the Jews to be the guiding regulations that Yahweh gave to them through Moses (Shectman 2016:67-88). The documentary hypothesis by Julius Wellhausen and the increasing criticisms from other scholars of the Pentateuch (Davies 2013:2-47; Gertz et al. 2016:1-16; Schmid 2016:589) seem to have punctured the previously held traditional notion of Mosaic authorship of the Pentateuch. A review of Wellhausen's hypothesis and subsequent scholarship on the actual author of the Pentateuch support multiple authorships. J, E, D and $P$ theory was used to point out the numerous authors that wrote the Torah. Considering the damning evidence that put Mosaic single authorship in doubt, we agree with scholars of the Pentateuch (e.g. Campbell \& O'Brien 2005:1-10; Gertz et al. 2016:1-7; Seters 2017:5-14) that issues of chronological lapses of storylines, duplication of narratives and so on cast a dark shadow on Mosaic single authorship claim. The peculiar content of Leviticus points to ' $\mathrm{P}$ ' (Priestly source) as the writer(s) of the text (King 2011:25). The recent debate on the source(s) or author(s) of Leviticus has projected an apparent exclusivity of ideas within the text particularly in Leviticus 17-26, as opposed to other parallel passages (Rendtorff 2003:1). The content and peculiarity of this part of Leviticus suggested a possible different source(s) or author(s). As rightly observed by Meyer (2015):

The authors of Lev17-26 were well acquainted with P, but they went much further than their priestly predecessors. Where Lev $1-16$ is mostly focused on the cult and the rituals associated with maintaining the cult, Lev17:26 broadens its horizons to include, amongst other things, what we might call 'ethical perspectives'. (p. 435)

Other scholars of Pentateuch and Leviticus studies (e.g. Joosten 1996:17-27; Milgrom 2003:24; Rhyder 2019:3) have lent their support to this new theoretical trend. We also agree with these scholars that the conspicuous peculiarities in Leviticus 17-26 are suggestive of additional writing contributions different from the rest of the writings of Leviticus. With incongruent and sometimes harsh/weird regulations within the text (Milgrom 2004:127-132), it seems challenging to many contemporary Christians and Jews to accept the book (comprising 27 chapters) as originating from Yahweh despite the introductory statement supporting 
such a notion (see Lv 1). Indeed, a great deal of evidence abounds, showing that the Book of Leviticus was written after the Babylonian exile by some anonymous Jews who ascribed the writing to a more influential patriarch - Moses (Najman 2010:73-76). This kind of pseudo-writing or ascribing authorship of a biblical text to prominent Jew(s) perhaps was an attempt to give some sort of credence or authority to the text. Despite this issue, literary/critical interpretation of extra-biblical materials gives credence to the presence of a disease similar to sara'at (Feder 2015:3) in the Ancient Near East (ANE), which includes Israel. The cardinal purpose of Leviticus was to direct the Jews on the part of holiness to Yahweh-God (Sprinkle 2015:32). The laws, rituals and sacrifices common in the book, especially in chapters 13 and 14, are not the only response to leprosy, but it was aimed at securing Israel's physical, moral and spiritual well-being (Gorman 1997:30-40), as perceived by the ancient Jews.

Leviticus chapters 13 and 14 discuss at length the laws guiding the diagnosis, separation and ritual treatment (for re-admittance into the camp) of a victim of leprosy (Olanisebe 2014:121-122). Parts of Leviticus 13, for instance, depict that a person who is declared unclean because they are infected with leprosy would be banished from the community and would undergo several mourning rites of wearing torn clothes and letting their hair hang loose (Skidmore 2020:893-900). Subsequently, the ritual killing of animals (birds) and the symbolic use of their blood for cleansing and readmitting of a leper into the camp (Jewish community) (Bonar 2004:257-277) form part of the focal points of chapter 14 . Although not clearly stated, a critical reading of the pericope of this study suggests that lepers were not only stigmatised (Deps \& Cruz 2020:1) but were thought to have been inflicted with the disease because of their personal shortcomings or 'punishment for their sins' (Grzybowski \& Nita 2016:3).

Ideas from Leviticus 13 and 14 portray Yahweh's central role in the activities and responses to the disease. The priests, as also depicted in the two chapters, performed religious as well as medical roles (Balentine 2002:19-40; Harrison 1980:150). Aside from clerical functions, the responsibilities of priests included diagnosing sara'at and supervising the implementation of its laws (Davies \& Davies 1989:622). The disease's aetiology was never mentioned in the two chapters. Baden and Moss (2011:643), in an effort to locate the origin of leprosy in Leviticus 13 and 14, found that the priestly laws give credence that Yahweh did not create the disease as punishment for sinners. However, in Numbers 12, Miriam's sara'at was inflicted on her as a punishment for criticising Moses. Evidence outside the Pentateuch (e.g. Chr 26:19-20 and $2 \mathrm{Sm} \mathrm{3:29)}$ also suggests that Yahweh uses leprosy as a punishment for sin. In spite of Baden and Moss' observation, the expression 'he is clean' in Leviticus. 14:20 is suggestive of Yahweh's forgiveness of a leper, which then resulted in healing. The forgiveness presupposes that the leper had suffered the disease because of uncleanness (i.e. sin). This style of linking uncleanness or sin to leprosy has a deep relationship with Yahweh's common strategy of punishing or striking people with leprosy for their misdeed or sin.

The ritual responses in the text ( $\mathrm{Lv} 13-14)$ are believed to be Yahweh's instruction to Moses and Aaron, who are leaders (Lv 13:1; 14:1). These leaders were greatly criticised by their followers for their misdeed and unrealisable socio-political aspirations/goals (Friedman, \& Friedman 2018:8; Hamilton n.d.:1-2). At different times and degrees, Moses and Aaron were challenged in the Pentateuch for poor leadership (Ex 16:2; Nm 14:1-4; Ex 15:24; Ex 15:24; Ex 5:1-22, Ex 14: 1112, Nm 11; Nm 12:1-12 etc.). The numerous grumblings against the leadership, including an attempt to kill Moses in Numbers 14:10, are indicative of conditions resulting from the intractable conflict. Even though Jews would be struck with either leprosy or death each time they rose against Moses or Yahweh, the conflict did not disappear after the wilderness experiences. From grumbling for lack of food, water and how to defeat their enemies (Friedman \& Friedman 2018:9-10), the issues of leprosy posed another setback to the leaders in Leviticus. Several offerings and rituals, as found in Leviticus 13 and 14, were coined as a way to mitigate the spread of the dreaded disease. These ritual responses agree with the scapegoat theory as mentioned earlier. Leviticus $4-5$, in part, show how laying on of hands and killing a bull and other animals became a way of atoning for sin. And because leprosy was believed to be a punishment for sin, the Jewish leaders with the help of the priests treated the victims of leprosy as if they were the cause of all the calamities that befell Israel at the time. No one remembered to question or blame Yahweh for using leprosy as a punishment for a misdeed or tried to find the medical breakthrough to cure or manage the disease. Although ignorance of the probable contagious property of leprosy could be a basis for the victimisation (Agbo 2012), it seems that the main goal was to shift blame from the leaders to the helpless lepers. As indicated in the scapegoat theory, scapegoated victims are often the most vulnerable and helpless members of society (Glick 2005:244-250). The lepers in the pericope of this study fit this description. Leviticus chapters 13 and 14 were conceived to be from Yahweh. Nonetheless, a critical analysis of the text influenced some contemporary scholars and lay people alike to doubt their moral or ethical relevance (Kellogg 2020; Olanisebe 2014:122). How could Yahweh order the inhumane ostracisation of lepers or suspected lepers, despite the horrendous psychological and physical pain on the victims? It could be that as the social mores evolved, ascribing every action (medical, social, political etc.) to Yahweh gave the leaders a sort of impetus for authority and legitimacy. With this instance in mind, it is fitting to explain the scapegoating experiences in Leviticus chapters 13 and 14 as politics of blame-game employed by the leaders to sustain their positions.

\section{Politics of blame-game during the outbreak of COVID-19 in Nigeria}

Robust literature on political leadership in Nigeria shows endemic corruption as the bane of development (Agbo et al. 2021:1-2; Campbell 2020:1; Chukwuemeka, Ugwuanyi \& 
Ewuim 2012:339; Izibili \& Aiya 2007:229; Ogbeidi 2012:3; Ogundiya 2017:281-282). In other words, Nigeria is experiencing a governance model linked to poor administration and increasing policy somersault (Okoye, Ibenwa \& Ekekwe 2021:122). Many Nigerians expressively score their leaders poorly as government officials usually blame the opposition party or previous administrations as the cause of underdevelopment, insecurity and poverty. Tignor (1993:175) observed that perhaps no country in the continent (Africa) has devoted more attention and energy to continuing allegations of corruption than Nigeria. The author also reported that numerous published reports had catalogued a wide range of iniquities perpetrated by Nigerian leaders. Emerging scholarly data on corruption in Nigeria show a worsening situation of the phenomenon (Keulder 2021:1). Corruption Perception Index 2020 ranked Nigeria 149th out of 179 countries (CPI 2021:2). The corruption situation in Nigeria is gravely worrisome. It seems the political leaders in Nigeria play politics without recourse to the sanctity of the life of their followers. Money meant for the provision of amenities to improve the life of Nigerians are recklessly embezzled. Healthcare, education, security and other critical sectors of the economy are in dire conditions owing to mismanagement and corruption. Equipment and facilities are vandalised for personal gain, mainly by government officials. It is not out of place to infer that the actions of previous and present Nigerian leaders clearly show that they are uninterested in the genuine progress or development of the country. Roughly 7 out of 10 Nigerians (72\%) believe that the statement 'most politicians are corrupt' describes their country well (Tamir 2019:2). It is to state the obvious that Nigerian leaders are heavily criticised for their bad governance motif, even before the emergence of COVID-19 in the area (Omonijo et al. 2013:2-3). Prior to the first case of COVID-19 in Nigeria, many had wondered how the virus would be put to an end because of government neglect of the healthcare sector, amongst other factors (Omaka-Amari et al. 2020:88).

How the governments at different levels (federal, state and local government) approached the outbreak of COVID-19 in Nigeria was consistent with their characteristic buck-passing and shifting of responsibility to the vulnerable citizens. For instance, at the onset of COVID-19 in Nigeria, it affected mainly government officials and the elite, all those who had an opportunity to travel abroad or work in the airports and their immediate families/relations (BBC News 2020:1). Incidentally, the partial lockdown that commenced on 04 May 2020 was aimed at the general population. Rather than a well-coordinated approach like what was obtainable in China, the Netherlands, the United States of America (US) and many European countries that experienced a restriction of movement during the outbreak of COVID-19, Nigeria government(s) hastily adopted lockdown protocols with draconic measures for the citizens. Unlike the support provided by the governments through the feeding of the citizens and other palliative measures in those countries, the Nigerian government enforced the lockdown measures with hardly any palliatives for the citizens (Iwuoha \& Aniche
TABLE 1: Cases of deaths and injured persons during the COVID-19 lockdown in Nigeria.

\begin{tabular}{llll}
\hline S/No. & Date & Area & Deaths and injured persons \\
\hline 1. & $\begin{array}{l}\text { 03 April } \\
2020\end{array}$ & $\begin{array}{l}\text { Adamawa } \\
\text { State }\end{array}$ & $\begin{array}{l}\text { The arbitrary use of firearms by police officers at } \\
\text { Damilu Mosque to disperse worshipers injured } \\
\text { about 20 persons. }\end{array}$ \\
2. & $\begin{array}{l}14 \text { April } \\
2020\end{array}$ & $\begin{array}{l}\text { Anambra } \\
\text { State }\end{array}$ & $\begin{array}{l}\text { The killing of two persons in Nkpor by police } \\
\text { officers whilst enforcing lockdown orders in the } \\
\text { State. }\end{array}$ \\
3. & $\begin{array}{l}\text { 15 April } \\
2020\end{array}$ & Abia State & $\begin{array}{l}\text { The death of a commercial driver who refused } \\
\text { to bribe an NSCDC officer on duty. }\end{array}$ \\
4. & $\begin{array}{l}\text { 16 April } \\
2020\end{array}$ & Abia State & $\begin{array}{l}\text { The killing of one Mr Ifeanyi Arunsi by drunken } \\
\text { police officers who were not on duty on } \\
\text { COVID-19 preventive assignment. }\end{array}$ \\
5. & $\begin{array}{l}\text { 23 April } \\
2020\end{array}$ & Rivers State & $\begin{array}{l}\text { A female police officer was shot dead by a } \\
\text { colleague who was attached to the State Taskforce } \\
\text { on decongestion and the destroying of goods, } \\
\text { wares and properties of the citizens in the state. }\end{array}$ \\
\hline
\end{tabular}

2020:632; Kazeem 2020:1-2). Some months after the lockdown was lifted, hoarded palliative materials worth millions of Naira were discovered in different locations in Nigeria (Agbedo et al. 2020:1). Government officials whose responsibility was to control the spread of the virus are said to have embezzled money set aside for the execution of their job as did in many parts of Africa (Shipani, Cotterill \& Munshi 2020:1-2). It was confusing to find out that the movement of people was restricted to avoid the spread of the virus, but the materials needed for their survival were heartlessly hoarded and mismanaged. Some of those who attempted to attend to their needs during this period were either injured or killed (see Table 1).

It is worrying that data from the Nigeria Centre for Disease Control (NCDC 2020:1) did not show significant community transmission of the virus during the period that the security officials had killed more people than those who died as a result of COVID-19. In another instance, two hotel buildings in River State, Nigeria were demolished through the orders of the state governor as customers allegedly violated the COVID-19 lockdown regulations (Orjinmo 2020:1). The destruction of hotel buildings because some customers did not follow COVID-19 social distancing measures seems a ruthless and high-handed approach amidst a conventional approach to enforcing the lockdown regulations. The injustices, violations of the human right of individuals and the embezzlement and mismanagement of funds and materials meant for cushioning the effects and spread of COVID-19, perhaps influenced Delia Rubio the Chair of Transparency International to add that COVID-19 pandemic is not just a health and economic crisis, but a corruption crisis and one that we are currently failing to manage (cited in Odunsi 2021:1).

Nigerian government officials at the federal, state and local government levels repeatedly announced to the people that all the policy measures applied as a response to COVID-19 are geared towards the protection of the citizens from the virus. Inferentially, those who were injured or killed were presented as black-sheep who wanted to destroy the economy and the existence of Nigeria through the spread of COVID-19. A critical appraisal of the governments' responses to COVID-19 in Nigeria indicates that the lockdown measures 
are linked to scapegoating mechanisms. Instead of taking the blame for (1) the poor control of the influx of people infected with COVID-19 into Nigeria (many government officials were the first to be diagnosed with the disease), (2) the poor healthcare delivery, (3) bad management of the lockdown protocols, and (4) the indifference in finding a vaccine or scientific solution to the virus, the Nigeria government treated those who violated the COVID-19 lockdown measures as if they masterminded the spread of the virus. The initial secrecy and concealing of information and data about the nature of the highly contagious nature of the virus by the Chinese government (Nie \& Elliott 2020:543; Zhu 2020:1873) contributed, in no small measure, to the spread of the virus from the Chinese city of Wuhan (where the virus was first diagnosed) to the rest of the world. A part of the blame ought to be apportioned to the Chinese government for this act. Many countries appeared to be careful in criticising China because of a possible backlash from the Chinese government and also perhaps owing to their strategic position in the global economy.

Drawing from the scapegoat theory, we could understand how the Nigerian leaders, in an attempt to absolve themselves from blame, profiled soft targets (the vulnerable citizens) that breached the COVID-19 lockdown protocols. Attention shifted from bad governance to the violators of the lockdown who were conceived as the cause of the spread of the dreaded virus. It is common knowledge that uncontrolled criticisms of the government could degenerate into protests in the form of the Arab Spring, a kind of revolution experienced in many Arab countries that led to a change of government in those countries. The government seemed to be conscious of this development arising from the increasing criticisms and bad leadership in Nigeria. And using blame-game politics as a decoy to protect leaders' self-image, ruthless policies were implemented during the COVID-19 lockdown period. The main objective was to single out those who violated lockdown protocols as scapegoats who bear all the blames for causing the spread of COVID-19 and the eventual socio-economic troubles in Nigeria.

\section{Costing the politics of blame-game as a response to leprosy in the Old Testament and COVID-19 in Nigeria}

The use of blame-game is an important strategy in politics. As earlier observed, many leaders (past and present) have employed blame-game mechanisms to protect their personal image and their administration from collapse. They leveraged this scapegoating construct to sustain their leadership, paying less attention to the emotional and painful experiences of the scapegoated individuals. For these leaders, apart from the selfish benefit of protecting their self-image/ positions, other implications arising from their policies are consciously neglected. The psychological trauma as a result of stigmatisation of lepers and suspected leprous patients in Leviticus 13 and 14 and other parallel verses were never considered. This group of vulnerable citizens was not only ostracised or banished from their community, but had to struggle with the destruction of their houses. The troubling effects of stigmatisation, poverty and homelessness, which had been captured by scholars (Arachichi et al. 2017:10; Courtwright 2009:92; Kidd 2007:291), were part of the experiences of the leprous patients and individuals suspected to be suffering from the disease in Leviticus and elsewhere in the OT. Interestingly, the state of their mental health was grossly neglected in the text under study. Although the Leviticus text being studied here is silent on the condition of these individuals (Davies 1988:136), common logic could point to the horrendous experiences they undergo because of possible challenges of basic human necessities needed for survival in the wilderness. Notwithstanding the fact that the Leviticus narrative also failed to include the possibility of great lack and deaths of some of the ostracised individuals, the rituals of re-admittance into the community (Olanisebe 2014:125) could as well suggest a celebration of life that was saved by providence. The public assumption that leprosy was a punishment from Yahweh as a result of sin, might have psychologically burdened the lepers into suicidal thoughts and hopelessness. As we know, amongst the causes of suicide is a perceived or real sense of hopelessness (Weishaar \& Beck 2009:117; Zhang \& Li 2013:790). The fact that this idea was not raised in the Book of Leviticus and in other parallel passages does not also preclude the non-existence of the situation.

Amongst the characteristics of leprosy is its contagious property (Lewis 1987:595). As a result, it is likely that those who destroyed the houses of lepers and the priests who attempted to diagnose leprosy exposed themselves to the pathogen (Agbo 2012:20). Although this idea is conspicuously lacking in the Book of Leviticus 13 and 14 and other parallel passages, it can be deduced by inference. The lack of genuine efforts of the leaders to find the medical solution to leprosy appears to be the basis for the victimisation, the frivolous rituals of re-admittance with probable financial and the psycho-social pressure heaped on the scapegoated victims. Again, Leviticus was silent on the source of the paraphernalia and ritual objects of cleansing and re-admittance. Even if the objects were contributed from the community, it goes on to show some levels of financial responsibility and stress on individuals or at the community level.

Moreover, the blame-game strategy as used by the Nigerian government during COVID-19 had ripple effects on many individuals and the nation at large. Many families experienced emotional pains as they grappled with the deaths and injuries to their loved ones (Busari 2021:1). There was hardly any government effort to help these families overcome the harrowing experiences of losing their loved ones and paying for the hospital expenses. At least, some members of the affected families needed not only financial assistance for the burial or treatment of the injuries in the hospital but also psychiatrists to attend to their mental health. Also worrisome is the waste of human resources through the injuries and deaths. The victims' future value 
and contribution to national development were not also considered, as they were killed. None of these bothered the governments' personnel and the leaders who acted to prove that the scapegoated victims were the ultimate cause of the spread of COVID-19 in Nigeria.

It is observable from the foregoing description that there exists obvious implication of blame-game politics as a response to the outbreak of leprosy and COVID-19 in the two societies under study. In a sense, the scapegoating mechanism leads to: (1) emotional health challenges of the scapegoats and their friends/family, (2) wastage of physical and human resources, (3) further spread of the disease and (4) lack of genuine interest to stop the spread of the disease. With this in mind, this article recommends a conscious and pragmatic effort from the leaders to curb or control the spread of pandemic-level diseases, learning from the effects of activities and policy responses to leprosy and COVID-19 in the two societies under study.

\section{Conclusion}

The outbreak of leprosy in Leviticus (OT) and COVID-19 in Nigeria led to policy changes expressed through blame-game politics. This governance strategy in the aforementioned societies during the outbreak of these diseases resulted in the victimisation of vulnerable citizens. The cost of these victimisations is experienced through the pains and emotional trauma of the scapegoated individuals and their family members and friends. Also, such politics of blamegame had led to increased neglect of the genuine solutions to tackle the spread of the diseases.

Indeed, one of the moral responsibilities of any government is to protect the lives and property of its citizens and to maximise effective participation and contribution towards national development. Far from the aforesaid idea is the use of blame-game politics as a decoy to victimise the citizens for the self-image of political actors and sustenance of their positions. This study provided evidence that the blame-game mechanism was used by the OT Jewish leaders as found in the Book of Leviticus 13 and 14, and in contemporary Nigerian society as a means to mitigate the spread of leprosy and COVID-19, respectively. Despite the positive review that supports scapegoating as an important variable in politics, this study makes a case to the contrary, owing to the breach of moral responsibility that supports the protection of people's right to life by their leaders. If leaders do not shun the politics of blame-game during future outbreaks of diseases, it might continue to lead to the needless and avoidable deaths of innocent individuals.

\section{Acknowledgements Competing interests}

The authors declare that they have no financial or personal relationships that may have inappropriately influenced them in writing this article.

\section{Authors' contributions}

The authors contributed equally to the writing of the article.

\section{Ethical considerations}

This article followed all ethical standards for research without direct contact with human or animal subjects.

\section{Funding information}

This research received no specific grant from any funding agency in the public, commercial or not-for-profit sectors.

\section{Data availability}

Data sharing is not applicable to this article as no new data were created or analysed in this study.

\section{Disclaimer}

The views and opinions expressed in this article are those of the authors and do not necessarily reflect the official policy or position of any affiliated agency of the authors.

\section{References}

Aborisade, R., 2021, 'Accounts of unlawful use of force and misconduct of the Nigerian Police in the enforcement of COVID-19 measures', Journal of Police and Criminal Psychology 36, 450-462. https://doi.org/10.1007/s11896-021-09431-4

Abubakar, R., 2021, 'COVID-19 and the acts of good governance in Nigeria's Fourth Republic', KIU Journal of Social Sciences 6(4), 17-28.

Adegbami, A. \& Adepoju, B., 2017, 'Good governance in Nigeria: A catalyst to nationa peace, stability and development', African Research Review 11(4), 144-155. https://doi.org/10.4314/afrrev.v11i4.12

Agbedo, O., Thomas-odia, I., Eze, O., Adewo, A., Akade, J., Njoku, L. et al., 2020, COVID-19 palliative and its controversies: Interrogating the looting spree dimension, viewed 23 April 2021, from https://guardian.ng/saturday-magazine/ covid-19-palliative-and-its-controversies-interrogating-the-looting-spreecovid-19-pallia
dimension/.

Agbo, P., 2012, 'Ignorance and the spread of leprosy \& HIV/AIDS: Old Testament and contemporary perspectives', PhD dissertation, University of Nigeria.

Agbo, P., Okoye, K., Uwaegbute, K. \& Agbo, C., 2021, 'From Nigeria/Biafra war to increasing ethnic conflict: The imperative of Nehemiah's administrative strategy', African Renaissance 18(1), 91-114. https://doi.org/10.31920/2516-5305/2021/ $18 \mathrm{n} 1 \mathrm{a} 5$

Akokuwebe, M. \& Adekanbi, D., 2017, 'Corruption in the health sector and implications for service delivery in Oyo State public hospitals, Ilorin', Journal of Sociology 9(1), 200-217.

Amadasun, S., 2020, 'COVID-19 palaver: Ending rights violations of vulnerable groups in Africa', World Development 134(1), 1-2. https://doi.org/10.1016/j. worlddev.2020.105054

Arachichi, M., Kumari, A., Wickramasinghe, R., Kuruppu, N. \& Madhavi, P., 2017, 'Stigmatisation in Leprosy: A descriptive study from patients' perspectives in Sri Lanka', Scientific Research Journal v(ix), 10-13.

Ayodeji, I. \& Adebayo, L., 2015, 'The interface between government policies, human capital development and poverty reduction in Nigeria', European Journal of Business and Innovation Research 3(4), 11-25.

Baden, J. \& Moss, C., 2011, 'The origin and interpretation of sāara'at in Leviticus 13-14', Journal of Biblical Literature 130(4), 643-662. https://doi.org/10.2307/23488272

Balentine, S., 2002, Leviticus interpretation: A Bible commentary for teaching and preaching, John-Knox Press, Louisville, KY.

Barnett, M. \& Duvall, R., 2005, 'Power in international politics', International Organization 59(1), 39-75. https://doi.org/10.1017/\$0020818305050010

BBC News, 2020, Coronavirus: Why some Nigerians are gloating about COVID-19, viewed 22 April 2021, from https://www.bbc.com/news/world-africa-52 372737.

Bonar, A., 2004, Commentary on the Book of Leviticus, viewed 06 August 2021, from https://faculty.gordon.edu/hu/bi/ted_hildebrandt/otesources/03-leviticus/text/ books/bonar-leviticus/bonar-leviticus.pdf.

Brustein, W. \& King, R., 2004, 'Anti-Semitism in Europe before the Holocaust', International Political Science Review 25(1), 35-53. https://doi.org/10.1177/ 0192512104038166 
Busari, K., 2021, Blood on uniforms: Inside horrific extra judicial killings by police officers enforcing COVID-19 lockdown in Kaduna, viewed 20 June 2021, from officers enforcing COVID-19 lockdown in Kaduna, viewed 20 June 2021, from uniforms-1-inside-extra-judicial-killings-by-police-officers-enforcing-covid-19uniforms-1-inside
lockdown.html.

Campbell, A. \& O'Brien, M., 2005, Rethinking the Pentateuch: Proglegomena to the theology of ancient Israel, John Knox, Westminster.

Campbell, J., 2020, Perceptions of corruption in Nigeria remain high, according to NGO, viewed 20 June 2021, from https://www.cfr.org/blog/perceptionscorruption-nigeria-remain-high-according-ngo.

Chukwuemeka, E., Ugwuanyi, B. \& Ewuim, N., 2012, 'Curbing corruption in Nigeria: The imperatives of good leadership', African Research Review 6(3), 338-358. https://doi.org/10.4314/afrrev.v6i3.25

Compton, T., 2006, Victim of the muses: Poet as scapegoat, warrior and hero in GrecoRoman and Indo-European myth and history, Hellenic Studies Series 11, Center fo Hellenic Studies, Washington, DC.

Courtwright, A., 2009, 'Justice, stigma, and the new epidemiology of health disparity', Bioethics 23(2), 90-96. https://doi.org/10.1111/j.1467-8519.2008.00717.x

CPI, 2021, Corruption perception index, viewed 10 April 2021, from https://www. transparency.org/en/cpi/2020/index/nzlon.

Crossman, A., 2019, Definition of scapegoat, scapegoating, and scapegoat theory: The origin of the term and overview of its use according to sociology, viewed 26 June 2021, from https://www.thoughtco.com/scapegoat-definition-3026572.

Dabang, P. \& Ukomadu, A., 2020, In Nigeria, looters target government warehouses stocked with COVID-19 relief, viewed 09 November 2020, from https://www. reuters.com/article/us-health-coronavirus-nigeria-food-idUSKBN27POVT.

Davies, G., 2013, 'Introduction to the Pentateuch' in J. Barton \& J. Muddiman (eds.), The Oxford Bible commentary, pp. 2-47, Oxford University Press, Oxford.

Davies, M., 1988, 'Levitical leprosy: Uncleanness and the psyche', The Expository Times 99(5), 136-139. https://doi.org/10.1177/001452468809900503

Davies, M. \& Davies, T., 1989, 'Biblical leprosy: A comedy of errors', Journal of Royal Society of Medicine 86(1), 622-623. https://doi.org/10.1177/0141076 88908201020

Dawson, D., 2013, Flesh becomes word: A lexicography of the scapegoat or, the history of an Idea, viewed 06 August 2021, from https://www.researchgate.net/ publication/290890577_Flesh_becomes_word_A_lexicography_of_the scapegoat_or_the_history_of_an_idea.

Deckard, N. \& Pieri, Z., 2017, 'The implications of endemic corruption for state legitimacy in dei appropriate?', The Journal of Theological Studies 58(1), 1-25.

Dellis, A., 2007, 'Blame-game politics in a coalition government', Journal of Public Economics 91(1-2), 77-96. https://doi.org/10.1016/j.jpubeco.2006.08.006

Demarest, L., 2020, 'Men of the people? Democracy and prebendalism in Nigeria's Fourth Republic National Assembly', Democratisation 28(4), 684-702. https://doi. org/10.1080/13510347.2020.1856085

Deps, P. \& Cruz, A., 2020, 'Why we should stop using the word leprosy', The Lance Infectious Diseases 20(4), 75-76. https://doi.org/10.1016/S1473-3099(20)30723-4

Ebekozien, A., 2020, 'Corrupt Acts in the Nigerian construction industry: Is the ruling party fighting corruption?', Journal of contemporary African Studies 38(3), 348-365. https://doi.org/10.1080/02589001.2020.1758304

Ehigie, B., Kolade, I. \& Afolabi, O., 2006, 'Personality factors influencing politicians' attitudes toward well-being of citizens: A study in Southwest Nigeria', International Journal of Public Sector Management 19(5), 428-446. https://doi. org/10.1108/09513550610677762

Ezeibe, C., Ilo, C., Ezeibe, E., Oguonu, C. \& Nwankwo, N., 2020, 'Political distrust and the spread of COVID-19 in Nigeria', Global Public Health 15(12), 1753-1766. https://doi.org/10.1080/17441692.2020.1828987

Feder, Y., 2015, 'Behind the scenes of a priestly polemic: Leviticus 14 and its extraBiblical parallels', Journal of Hebrew Scriptures 15(4), 1-26. https://doi. org/10.5508/jhs.2015.v15.a4

Friedman, H. \& Friedman, L., 2018, 'Even great leaders make mistakes: Learning leadership from Moses', Journal of Leadership and Management 13(3), 3-32.

Gallese, V., 2009, 'The two sides of mimesis: Girards's mimetic theory, embodied simulation and social identification', Journal of Consciousness Studies 16(4), 21-44.

Gertz, J., Levinson, B., Rom-Shiloni, D. \& Schmid, K., 2016, 'Introduction', in J. Gertz, B. Levinson, D. Rom-Shiloni \& K. Schmid (eds.), The formation of the Pentateuch, pp. 1-16, Mohr Sieback, Tübingen.

Gibson, J., 2007, 'Russian anti-Semitism and the Scapegoating of Jews', British Journa of Political Science 37(2), 193-223. https://doi.org/10.1017/S0007123407000105

Glick, P., 2002, 'Sacrificial lambs dressed in wolves' clothing: Envious prejudice, ideology, and the scapegoating of Jews', in L. Newman \& R. Erber (eds.) Understanding genocide: The social psychology of the Holocaust, pp. 126-130, Oxford University Press, Oxford.

Glick, P., 2005, 'The choice of scapegoats', in J. Dovidio, P. Glick \& L. Rudman (eds.), On the nature of prejudice: Fifty years after Allport, Wiley Publications, Hoboken, NJ.

Gorman, F., 1997, Divine presence and community: A commentary on the Book of Leviticus, B. Eerdmans Publishing, Grand Rapids, MI.

Grzybowski, A. \& Nita, M., 2016, 'Leprosy in the Bible', Clinics in Dermatology 34(1), 3-7. https://doi.org/10.1016/j.clindermatol.2015.10.003

Hamilton, D., n.d., The danger of grumbling, viewed 09 August 2021, from http:// camphillchurch.org/publication_files/the-dangers-of-grumbling.pdf.

Hammer, E., 2007, 'Scapegoat theory', in F. Baumeister \& D. Kathleen (eds.), Encyclopedia of social psychology, Sage publications, Los Angeles, CA.
Hansson, S., 2017, 'Analysing opposition- government blame-games: Argument models and strategic Maneuvering' Critical Discourse Studies 15(2), 472-492. models and strategic Maneuvering', Critical Discour
https://doi.org/10.1080/17405904.2017.1405051

Harrison, R., 1980, Leviticus (Tyndale Old Testament Commentary / TOTC), vol. 3, InterVasity Press, Westmont, IL.

Heike, T., 2018, 'Priestly leadership in the book of Leviticus: A hidden agenda', in P. Katharian \& S. Schulz (eds.), Debating authority, concepts of leadership in the Pentateuch and the former prophets, pp. 68-88, DeGruyter, Berlin.

Hinterleitner, M., 2018, 'Policy failures, blame games and changes to policy practice', Journal of Public Policy 38(2), 221-242. https://doi.org/10.1017/S0143814X 16000283

Hinterleitner, M. \& Sager, F., 2016, 'Anticipatory and reactive forms of blameavoidance behaviour: Of foxes and lions', European Political Science Review 9(4), 587-606. https://doi.org/10.1017/S1755773916000126

Hood, C., 2002, 'The risk game and the blame game', Government and Opposition 37(1), 15-37. https://doi.org/10.1111/1477-7053.00085

Hood, C., 2010, The blame-game: Spin, bureaucracy, and self-preservation in government, Princeton University Press, Princeton, NJ.

Hood, C., Jennings, W. \& Copeland, P., 2016, 'Blame avoidance in comparative perspective: Reactivity, staged retreat and efficacy', Journal of Public Administration 94(2), 542-562. https://doi.org/10.1111/padm.12235

Houston, W., 2007, 'The character of YHWH and the ethics of the Old Testament: Is Imitatio Dei appropriate?', The Journal of Theological Studies 58(1), 1-27. https:// doi.org/10.1093/jts/fll036

Iwuoha, V. \& Aniche, E., 2020, 'COVID-19 lockdown and physical distancing policies are elitist: Towards an indigenous (Afro-centred) approach to containing the pandemic in sub-urban slums in Nigeria', Local Environment 25(8), 631-640. https://doi.org/10.1093/jts/fll036

Izibili, M. \& Aiya, F., 2007, 'Deregulation and corruption in Nigeria: An ethical response', Journal of Social Sciences 14(3), 229-234. https://doi.org/10.1080/097 18923.2007.11978353

Joosten, J., 1996, People and land in the holiness code: An exegetical study of the ideational framework of the law in Leviticus 17-26, Brill, Leiden.

Katana, E., Amodan, B., Bulage, L., Ario, A., Fodjo, J., Colebunders, R. et al., 2021, 'Violence and discrimination among Ugandan residents during the COVID-19 lockdown', BMC Public Health 21(467), 1-13. https://doi.org/10.1186/s12889-021-10532-2

Kazeem, Y., 2020, Ordinary Nigerians are filing the country's major social welfare gaps amid coronavirus, viewed 20 March 2021, from https://qz.com/africa/1843839/ nigerias-coronavirus-lockdown-is-hitting-poor-families-hard.

Keulder, C., 2021, Africans see growing corruption, poor government response, but fear Retaliation if they speak out, viewed 02 May 2021, from https:// afrobarometer.org/sites/default/files/publications/Dispatches/ad421-africans see_growing_corruption-afrobarometer_dispatch-bh-24jan20.pdf.

Kellogg, S., 2020, The book of Leviticus, BoD Books, Frankfurt.

Kidd, S., 2007, 'Youth, homelessness, and social stigma', Journal of Youth and Adolescence 36(3), 291-299. https://doi.org/10.1007/s10964-006-9100-3

King, G., 2001, 'The documentary hypothesis', Journal of the Adventist Theological Society 12(1), 22-30.

Kirwan, M., 2005, Discovering Girard, Cowley Publications, Lanham, MD.

Langford, J., 2011, 'The blame game: Spin, bureaucracy, and self-preservation in government', Canadian Public Administration 54(4), 595-598. https://doi. org/10.1111/j.1754-7121.2011.00199.x

Lee, F. \& Robinson, R., 2000, 'Social accounts: Implications of playing the blamegame', Journal of Applied Social Psychology 30(9), 1853-1879. https://doi. org/10.1111/j.1559-1816.2000.tb02472.x

Lewis, G., 1987, 'A lesson from Leviticus: Leprosy', Man New Series 22(4), 593-612. https://doi.org/10.2307/2803354

Lumumba, P., 2014, 'Corruption the bane of Africa', in E. Nduku \& J. Tenamwenye (eds.), Corruption in Africa: A threat to justice and sustainable peace, pp. 17-30, Globethics, Geneva.

Mallan, K., 2013, 'The scapegoat', in K. Mallan \& C. Bradford (eds.), Secrets, lies and children's fiction, pp. 65-89, Palgrave Macmillan, London.

Margaliot, M., 1983, 'The transgression of Moses and Aaron: Num. 20:1-13', Jewish Quarterly Review 74(2), 196-228. https://doi.org/10.2307/1454384

Mellema, G., 2010, 'Scapegoats', Criminal Justice Ethics 19(1), 3-9. https://doi.org/10 .1080/0731129X.2000.9992080

Meyer, E., 2015, 'People and land in the holiness code: Who is YHWH's favourite?', Old Testament Essays 28(2), 433-450. https://doi.org/10.17159/2312-3621/2015/ V28N2A12

Milgrom, J., 2003, ' $H_{8}$ in Leviticus and elsewhere in the Torah', in R. Rendtorff \& R. Kugler (eds.), The book of Levitius: Composition and reception, pp. 127-132, Brill, Leiden.

Milgrom, J., 2004, Leviticus: A book of ritual and ethics: Continental commentaries, Fortress Press, Minneapolis, MN.

Modebadze, V., 2010, 'The term politics reconsidered in the light of recent theoretical developments', IBSU Scientific Journal 1(4), 39-44.

Najman, H., 2010, Past renewals: Interpretative authority, renewed revelation and the quest for perfection in Jewish antiquity, Brill, Leiden.

NCDC, 2020, An update of COVID-19 outbreak in Nigeria, viewed 12 January 2021 , from https://ncdc.gov.ng/diseases/sitreps/?cat=14\&name=An $\% 20$ update $\% 20$ of $\% 20$ COVID- $19 \% 20$ outbreak $\% 20$ in $\% 20$ Nigeria. 
Nie, J. \& Elliott, C., 2020, 'Humiliating whistle-blowers: Li Wenliang, the response to Covid-19', Journal of Bioethical Inquiry 17(4), 543-547. https://doi.org/10.1007/ s11673-020-09990-x

Niyimbanira, F. \& Madzivhandila, T., 2016, 'Myth that immigrants "steal jobs": An economic blamegame', International Journal of Social Sciences and Humanity Studies 8(2), 165-179.

Nnoli, O., 2003, Introduction to politics, Snaap Press, Enugu.

Norz, J., 2015, The danger of playing the blame-game, viewed 22 February 2021, from https://www.corporatecomplianceinsights.com/the-danger-of-playing-theblame-game/.

Oboirien, K., 2020, Human rights violations during COVID-19 in Nigeria, viewed 26 June 2021, from https://www.linkedin.com/pulse/human-rights-violationsduring-covid-19-nigeria-oboirien.

Odigbo, B., Eze, F., \& Odigbo, R., 2021, 'COVID-19 lockdown controls and human rights abuses: The social marketing implications', Emerald Open Research 2(45), 1-18.

Odukoya, J., Bowale, E. \& Okunlola, S., 2018, 'Formulation and implementation of educational policies in Nigeria', African Educational Research Journal 6(1), 1-4.

Odunsi, W., 2021, Corruption: Transparency International ranks Nigeria 149 on list of 180 countries, viewed 01 July 2021, from https://dailypost.ng/2021/01/29/ corruption-transparency-international-ranks-nigeria-149-on-list-of-180countries/.

Ogbeidi, M., 2012, 'Political leadership and corruption in Nigeria since 1960: A socioeconomic analysis', Journal of Nigeria Studies 1(2), 1-25.

Ogundiya, I., 2017, 'Political corruption in Nigeria: Theoretical perspectives and some explanations', The Anthropologist 11(4), 281-292. https://doi.org/10.1080/09720 073.2009.11891117

Okoye, K., Ibenwa, C. \& Ekekwe, E., 2021, 'Beyond the rhetoric of educational policy in Nigeria: Understanding the state actors neglect on education the COVID-19 pandemic', Journal of International Cooperation and Development 4(1), 117-130. https://doi.org/10.36941/jicd-2021-0007

Olanisebe, S., 2014, 'Laws of tzara'at in Leviticus 13-14 and medical leprosy compared', Jewish Bible Quarterly 42(2), 121-127.

Olujobi, O. \& Olujobi, O., 2020, 'Comparative appraisal of anti-corruption laws: Lessons Nigeria can learn from Norway, United Kingdom and United States' anti-
corruption strategies', International Journal of Management 11(7), 338-347. corruption strategies', International Journal
https://doi.org/10.4018/IJESGT.2020070105

Omaka-Amari, L., Aleke, C., Ogbande-Ogbuinya, N., Ngwakwe, P., Nwankwo, O. \& Afoke, E., 2020, 'Coronavirus (COVID-19) pandemic in Nigeria: Preventive and control challenges within the first two months of outbreak', African Journal of Reproductive Health 24(2), 88-97.

Omonijo, D., Nnedum, O. \& Uche, O., 2013, 'Social perspectives in the pervasiveness of endemic corruption in Nigeria', International Journal of Economics, Commerce and Management $1(2), 1-26$

Onigbinde, O., Babatunde, O. \& Ajagbe, A., 2020, 'The welfare of healthcare workers amidst COVID-19 pandemic in Sub-Sahara Africa', Ethics Med Public Health. https://doi.org/10.1016/j.jemep.2020.100555

Orjinmo, N., 2020, 'Coronavirus lockdown: Two hotels demolished in Nigeria for "breach of rules"', BBC News, viewed 01 January 2021, from https://bbc.com./ news/world-africa-52617552.

Palaver, W., 2010, 'Violence and religion Walter Burkert and René Girard in comparison', Contagion: Journal of Violence, Mimesis, and Culture 17(1), 121-138. https://doi.org/10.1353/ctn.2010.0007
Perera, S., 1986, 'Scapegoat complex: Toward a mythological shadow and guilt', Public Policy 38(2), 221-242.

Rendtorff, R., 2003, 'Introduction', in R. Rendtorff \& R. Kugler (eds.), The Book of Leviticus: Composition and reception, pp. 1-5, Brill, Leiden.

Rhyder, J., 2019, Centralising the cult: The holiness legislation in Leviticus 17-26, Mohr-Siebeck, Tubigen.

Schmid, K., 2016, 'Post-priestly additions in the Pentateuch - A survey of scholarship', in J. Gertz, B. Levinson, D. Rom-Shiloni \& K. Schmid (eds.), The formation of the Pentateuch, pp. 589-561, Mohr Sieback Tübingen.

Schultz, J., 2002, Commentary to the Book of Leviticus, viewed 09 August 2021, from https://www.bible-commentaries.com/source/johnschultz/BC_Leviticus.pdf.

Seters, J., 2017, The Pentateuch: A social-science commentary, Bloomsbury Publishing, London.

Shectman, S., 2016, 'Themes and perspectives in Torah: Creation, kinship, and covenant', in G. Yee, H. Page, \& M. Coomber (eds.), The Pentateuch: Fortress commentary on the Bible study edition, Fortress Press, Minneapolis, MN.

Shipani, A., Cotterill, J. \& Munshi, N., 2020, 'Africa's Covid-19 corruption: Theft doesn't even stop during a pandemic', Financial Times, viewed 24 April 2021, from https:// www.ft.com/content/617187c2-ab0b-4cf9-bdca-0aa246548745.

Shurafa, C., Darwish, K. \& Zaghouani, W., 2020, 'Political framing: US COVID-19 blame-game', in S. Aref, M. Braghieri, F. Giannotti, D. Pedreschi, K. Bontcheva \& F. Grisolia (eds.), Conference proceedings on social informatics, pp. 333-359, Springer, Cham.

Skidmore, S., 2020, 'The evolution of the șāra'at ritual in Leviticus 13:1-46', The Heythrop Journal 61(6), 893-902. https://doi.org/10.1111/heyj.13687

Sprinkle, J., 2015, 'Introduction to Leviticus', in M. Strauss \& J. Walton (eds.), Teach the text commentary, Leviticus and Numbers, Baker Books, Grand Rapids, MI.

Tamir, C., 2019, 'As elections near, Nigerians view their country's economy and political system negatively', Pew Research Center, viewed 02 December 2020 from https://www.pewresearch.org/fact-tank/2019/02/12/as-elections-nearnigerians-view-their-countrys-economy-and-political-system-negatively/.

Tignor, R., 1993, 'Political corruption in Nigeria before independence', The Journal of Modern African Studies 31(2), 175-202.

Vandenhole, W., 1996, 'Rwanda and Genocide in the twentieth century by Alain Destexhe (book review)', Journal of Modern African Studies 34(2), 345-347. https://doi.org/10.1017/S0022278X00055361

Weishaar, M. \& Beck, A., 2009, 'Hopelessness and suicide', International Review of Psychiatry 4(2), 177-184. https://doi.org/10.3109/09540269209066315

Wenham, G., 1979, The New International Commentary on the Old Testament: The Book of Leviticus, viewed 12 August 2021, from https://www.scribd.com/ $\mathrm{read} / 482517145 /$ The-Book-of-Leviticus\#on.

Wittes, T., 2016, Politics, governance and state society relation: Real security, the interdependence of governance and stability in the Arab world, A working group
report of the middle east strategy task force, viewed 26 June 2021, from https:// www.brookings.edu/wp-content/uploads/2016/11/cmep_201611_mest_paper final.pdf.

Zhang, J. \& Li, Z., 2013, 'The association between depression and suicide when hopelessness is controlled for', Comprehensive Psychiatry 54(7), 790-796. https:// doi.org/10.1016/j.comppsych.2013.03.004

Zhu, J., 2020, 'Is it ethical to be a "Whistle-blower" during COVID-19 pandemic? Ethical challenges confronted by healthcare workers in China', Journal of Advanced Nursing 76(8), 1873-1875. https://doi.org/10.1111/jan.14376 